\title{
Regional Industrialisation without National Growth: \\ The Catalan Industrialisation and the \\ Growth of Spanish Economy \\ (1830-1861)
}

(November 2003)

Joan R. Roses

Department of Economics; Universitat Pompeu Fabra

C/ Ramón Trias Fargas 21-23, 08003 Barcelona, Spain

e-mail: joanramon.roses@upf.edu

and

Department of Economic History and Instituto Laureano Figuerola

Universidad Carlos III de Madrid

C/ Madrid 126, 28903 Getafe, Madrid, Spain

\begin{abstract}
This paper has two main objectives. First, it provides a stylised description of the Catalan industrial path of the period 1830-1861. Second, it reviews the evolution of the Catalan industry in the Spanish context and, thus, can serve to describe the relative importance of the Catalan industrial experience. Consequently, it is mainly devoted to computing and analysing the growth rates of Catalan industries during the early phase of industrialisation. The results show that Catalonia experienced a true process of industrialisation during the period 1830 to 1861, but that its contribution in rapid increase in Spanish GDP was relatively small.
\end{abstract}

Keywords: Industrial production; regional divergence; Divisia indices.

JEL codes: N63; O14; N93. 


\section{Introduction}

The measurement of the industry growth rates has a major role in the debate on the nature and characteristics of the beginnings of industrialisation. Pioneering work on industrial output indices was based on the well-known non-superlative indices, such as Laspeyres or Paasche. These indices tend to concede large shares to the new sectors, cotton textiles and iron, within industrial output. In broad terms, all these exercises tend to stress the existence of an explosive beginning where overall industry growth rates were fast. By contrast, this explosive view has been challenged more recent work using superlative indices such as Fisher or Divisia. Critics of the explosive beginnings have pointed out that only new industries experienced fast growth rates whereas the rest of industries remained in pre-modern backwardness (see, for example, Crafts and Harley 1992). Their analyses were based on a revisionist assessment of the size of the modern industries, with the implication that estimates of aggregate industrial growth should be lowered appreciably for the period of early industrialisation.

A similar debate also took place in the Spanish literature. Albert Carreras (1990) has pointed out that during the early period, 1830-1861, industrial growth rates were above 4 percent and that the share of the textile and metal industries, the modern industries, in Spanish industrial value-added was about 45 percent. Moreover, he argued that early industrialisation was characterised by an abrupt change in industrial output. By contrast, Leandro Prados de la Escosura (1988), a critic of the explosive beginnings, has pointed out that the share of modern industries of value-added was lower than Carreras suggested. By reducing the share of modern industries and considering more industries, he developed a new index with slow growth rates (about 2 percent per year).

Albert Carreras (1990) has also computed an industrial index for Catalonia with fast growth rates (above 6 percent per year). However, the revision of that index by Jordi Maluquer de Motes (1994) has not changed the general view on Catalan industrialisation. This economic historian reduced the share of cotton of value-added and considered more industries, but the resulting growth rates remained impressive for this early industrialisation period (about 6 percent per year). 
Unfortunately, the stimulating revisions of Carreras' indices have not dealt with two important methodological (index) problems. First, Prados de la Escosura and Maluquer de Motes did not compute changes in the quality of output. In contrast, they assumed the quality remained constant throughout the period, since their quantity indices are the result of multiplying the gross weight of the main raw materials by a fixed coefficient. ${ }^{1}$ It should be noted that this kind of procedure is likely to understate growth rates of modern sectors, where quality change was very important. Second, Maluquer de Motes and Prados de la Escosura weighted their indices with the last year weights assuming, implicitly, that the relative prices remained constant throughout the entire period. It is well known that this assumption overstates the rate of growth. ${ }^{2}$ Therefore, in order to measure correctly the industry growth rates, a different kind of index number is necessary. For that reason, the main objective of this paper is to recalculate industry growth rates in Catalonia from 1830 to 1861, employing a different kind of index number. Using a superlative index number, specifically a Törqvist index, one is able to solve the two shortcomings mentioned above.

It should be noted that there are important limits to the degree to which growth estimates for many Catalan industries can be developed, since data is not available for the whole manufacturing sector. Thus, only the following sectors can be studied, cotton spinning, cotton weaving, cotton finishing, linen, metal, mixed fabrics, paper, silk and wool. We use two benchmark years: 1840 and 1861. However, it should be noted that, empirically, the industrial growth rate is determined by three different findings: the rate of growth of the modern industries, their share in the industrial output, and the rate of growth of pre-modern industries. If the rate of growth and share of modern industries is large enough, overall growth rates are

\footnotetext{
${ }^{1}$ In both studies Prados de la Escosura and Maluquer recognized the existence of these biases and the possible influence in the resulting growth rates (Prados de la Escosura 1988, pp. 148 and Maluquer 1994, pp. 51-53).

${ }^{2}$ It should be noted that Prados de la Escosura only employed Laspeyres indices for 18301860 , since in the rest of periods he employs Divisia indices. The reason is that there is not enough data to construct the two benchmark estimates necessary for Divisia weights (Prados de la Escosura 1988, pp. 145-147).
} 
necessarily higher. Consequently, by estimating the share and growth rates of modern industries we can calculate a range of plausible growth rates.

The plan of this paper is as follows. Section 2 discusses the construction of a new annual index for the Catalan cotton industry for 1830 to 1861 . It should be noted that growth findings in cotton industry are very important since it was the main Catalan industry during the period and, therefore, its growth rates heavily influence the results. The next section describes the elaboration of new production measures for the other Catalan manufacturing industries for the period 1840 to 1861. In section 4, I present a brief analysis of the results and the contribution of Catalan industry to Spanish growth rates. The bulk of the paper then takes up the technical and empirical issues related to the construction of the new measures for Catalan manufacturing.

\section{A New Yearly Index of Cotton Industry Production (1830-1861)}

The objective of this section is to develop Törqvist indices (also called Divisia or Translog) of sectoral (gross) output for the cotton industry and its sub-components (spinning, weaving and finishing). This is not the first time that attempts have been made to compute the value of the production of the Catalan cotton textile industry. Albert Carreras (1990), Carles Sudrià (1983), Leandro Prados de la Escosura (1983)(1988) and Jordi Maluquer de Motes (1994) have proposed different figures for Catalan cotton industry production in the XIX ${ }^{\text {th }}$ Century.

To compute consumption of cotton cloth, all these economic historians have transformed the raw material figures by means of fixed coefficients into output figures. More specifically, all have hypothesised that the quantity of raw cotton imported minus 10 percent of wastage was equal to the quantity of cotton cloth produced. ${ }^{3}$ This method is likely to produce a downward estimate of the output

\footnotetext{
${ }^{3}$ However, it should be noted that Maluquer de Motes (1994) has employed two different wastage measures: until 1870 he assumed 10 percent wastage, whereas after this year he progressively reduced the wastage because new machinery capable of reducing raw cotton losses was introduced.
} 
indices, since it does not consider the increase in the quality of output. ${ }^{4}$ However, they have differed in the type of quantity index used to aggregate these figures on cotton consumption. Thus, the non-superlative indices had been employed by Carreras and Maluquer de Motes whereas the superlative had been used by Prados de la Escosura. It should be noted that the superlative indices have several important advantages over the non-superlative indices. The first type of indices assumes a constant elasticity of substitution among the factors of production. If the choice is a non-superlative index, the analysis of the interrelations among the factors of production is biased, because a correct measure of growth must consider that sometimes the innovation implies changes in the elasticity of substitution, and the output measure necessarily assumes that there were no changes in the quality of production. For this reason, modern growth accounting, and growth measurement, has abandoned these indices and introduced superlative indices. These indices assume multiple elasticities of substitution among the factors of production. The best-known superlative indices are the Fisher and the Divisia (also called Törnqvist). The first assumes a quadratic production function and the second a Translog production function. Both production functions assume, obviously, multiple elasticities of substitution among the factors of production and quality changes during the period considered (Diewert 1987, Diewert and Nakamura 1993, and Hill 1993).

Several steps must be carried out to solve the two major flaws present in the previous studies. First, a new technique is used for computing the yearly amount of raw cotton that was employed by the industry and the wastage as result of the spinning and weaving process. Second, according to the most recent practices, the exact measure of quantities are not an unweighted sum but a bilateral quantity index that is a weighted average of quantity relatives (Hill 1993). Then, one of the primary objectives for output measures is to start with as much detail or disaggregation of the measured outputs as possible. It is also convenient that subaggregates are homogeneous. ${ }^{5}$ The intent is to develop output indices that correctly

\footnotetext{
4 The same Prados de la Escosura (1988) discusses these biases.

${ }^{5}$ Sub-aggregates are homogeneous when the price dispersion of their components is not 
reflect the differing trends in the output of the variety of goods produced within the industry. Third, to combine quantities and prices in a single measure Törqvist indices must be employed due to their conceptual advantages. Finally, according to the Törqvist index methodology, the weights of the industry must be computed as the average value in the period.

To measure output, I use Törnqvist quantity indices, which are the changingweight indices that have been used most frequently in the literature on productivity measurement. These indices make use of logarithms for comparing a variable at two points of time. When used to compare outputs for two time-periods, they employ an average of value-share weights for the two periods being considered. The index number is computed after first determining the logarithmic change as follows:

$$
\ln X_{t}-\ln X_{t-1}=\sum_{i}\left[\bar{\Theta}_{X_{i}}\left(\ln x_{i_{t}}-\ln x_{i_{t-1}}\right)\right]
$$

Where xi designates outputs, where $n$ outputs (1..i..n) are being considered, the two time periods are $t$ and $t-1$, and the value share weights $\Theta_{x i}$ are computed as:

$$
\begin{gathered}
\bar{\Theta}_{X_{i}}=1 / 2\left[\theta_{x i}(T)+\theta_{x i}(T-1)\right], \\
(i=1, . . i, . . n) .
\end{gathered}
$$

Where the $\Theta_{x i}$ 's denote the share of each output in total payments to its aggregate outputs. The exponential of this logarithmic change yields an index number.

Following the methodology of Jorgenson (1990), the starting point for the construction of Törnqvist indices of sectoral (gross) output is the measurement of the total product in current prices (i.e., the measurement of total payments). Empirically, the total product in current prices is equal to the sum of the values of all components of output or, equivalently, to the result of multiplying quantities by the unit prices of each component. Here, the system chosen to calculate the total output has been to compute yearly quantities of output and multiply these by their current prices (unit values). Because it is not convenient to employ a unique value for cotton spinning, weaving and finishing, I compute their values employing up to five unit values and

statistically significant. 
output categories for each of these sub-sectors.

Consequently, to construct these estimates of total product it is necessary to establish quantities of inputs and to infer quantities of outputs. For spinning, the yearly production of the five qualities of yarn has been inferred from the consumption of raw cotton. It should be noted that this procedure is possible given that each quality of yarn can only be produced by a particular combination of different types of raw cotton. For weaving, the production of the five qualities of grey cloth has been inferred from the estimated consumption of the five different qualities of yarn. Finally, for finishing, the quantity of the five qualities of finished cloth has been derived from the estimated consumption of the five qualities of grey cloth.

The previous calculations used two different systems to estimate the yearly consumption of raw cotton by the Catalan industry. Albert Carreras and Leandro Prados de la Escosura used the importation figures directly, whereas Carles Sudrià and Jordi Maluquer created new figures because they transformed the original figures by means of a three-year average centred on the middle year. The latter argued that this mathematical transformation is necessary because the yearly fluctuations of the importations figures are excessive. Moreover, Jordi Maluquer added to the import figures the Spanish raw cotton that was produced in Motril and imported through the Port of Barcelona, which was the main entrance for the raw materials used by the Catalan cotton industry. The Carreras-Prados de la Escosura solution implies that all the imported raw cotton was transformed into final products during the year in which they arrived in Catalonia. Therefore, there were no stocks of raw cotton in the hands of the wholesalers or semi-finished products in the hands of the cotton industry. Obviously, this does not seem plausible. On the other hand, the Sudrià-Maluquer solution implies that the quantity of raw cotton consumed by the industry in one year must necessarily depend on the quantity of raw cotton that would be imported during the following year. This also does not seem plausible. Therefore, the solution adopted in this paper is quite different from these two proposals.

The departure point for the computation of the quantities of raw cotton is to add to the original importation figures (Nadal 1974) Motril's raw cotton sold in the Port of Barcelona (Comisión del Gobierno 1841). Where there are no figures for the 
Motril raw cotton trade, it is hypothesised that the Motril raw cotton figures maintained a straight-line relation with the trade of American raw cotton. Second, from 1850 to 1861 , figures on the raw cotton imports are drawn from Diario de Barcelona (1866). Third, mobile averages that differ strongly from Sudrià-Maluquer's have been computed in order to transform the original import figures to production figures. Thus:

$$
\text { Quantity } \left.\left(\text { Yeart }_{t}\right)=0.8 * \text { Imports }\left(\text { Yeart }_{t}\right)+0.2 * \text { Imports }(\text { Yeart }-1)\right)
$$

The choice of this mobile average has been based on different historical evidence: the quantity of raw cotton and intermediate products that different cotton firms declared as having in their factories (Comisión especial arancelaria 1867), literary evidence on the stocks of raw cotton, and the recommendations of different historical technical books on the problems of storing raw cotton for long periods (Arau 1855, Calvet 1857, and Ronquillo 1851-1857). Thus, different averages have been computed for nine unusual years (i.e. about 30 percent of years), although these maintain the raw cotton stock for no more than two years. ${ }^{6}$

All the previous studies assume that wastage of the raw cotton during the spinning and weaving process was equal to ten percent of its weight. However, wastage was not constant because it varied with the quality of raw cotton. In his study on the Lancashire cotton industry, Huberman (1996) divided raw cotton into five qualities (G1, G2, GF, F1 and F2), from the coarsest to the finest, matching to each quality a different wastage during the spinning process. Wastage was of nine percent for quality G1 and grew successively by one percent for each quality because the best qualities that were employed to produce the finest yarn suffered most friction during the spinning process. He derived these five figures by observing the places of production of the raw cotton, since quality depended on the place where the raw cotton was produced.

\footnotetext{
${ }^{6}$ In particular: $1844(0.6$ Yeart +0.2 Yeart-1); $1845(0.8$ Yeart +0.4 Yeart-1); 1850 (0.7Yeart + 0.3 Yeart -1$) ; 1851$ (0.8Yeart +0.3 Yeart-1); $1856(0.6$ Yeart +0.2 Yeart-1 $) ; 1857$ (0.8Yeart + 0.4 Yeart-1); 1858 (Yeart + 0.2Yeart-1); 1859 (0.9Yeart); 1860 (0.8Yeart + 0.1Yeart-1).
} 
In this study, the quality figures have been drawn from the Diario de Barcelona (1866), in which was listed the producing places of the raw cotton bales and their weights, from 1851 to 1861 . However, this source only specified the producing countries and not the different locations within each country. Concerning the United States, this incompleteness in the sources is important because Huberman (1996) has computed the quality of British yarn by referring to three different producing locations in the United States (Sea Island, Upland and Alabama). For this reason, the raw data for 1850 (Ronquillo 1851-1857), which distinguished the producing locations of raw cotton for different regions within the United States, has been extrapolated to the following years. Moreover, the Huberman equations have been modified slightly to adapt to the Catalan procedures, which are described in different technical handbooks (Arau 1855, Calvet 1857). The results are in the equations below: 7

(4)

$$
\begin{aligned}
& \mathrm{C} 1=0.30(\mathrm{US})+(\text { India and China })+(\text { Levant }) \\
& \mathrm{C} 2=0.50(\mathrm{US}) \\
& \mathrm{CF}=0.19(\mathrm{US})+0.50(\text { Brazil })+(\text { Motril and Puerto Rico }) \\
& \mathrm{F} 1=0.50(\text { Brazil }) \\
& \mathrm{F} 2=0.01(\mathrm{US})+(\text { Egypt })
\end{aligned}
$$

For the period before 1850, the wastage had to be calculated in a different way. Different estimates on the counts (quality) of the yarn produced by the Catalan industry were available for 1840, 1846 and 1849 (Madoz 1846 and Figuerola 1968). Thus, if one treats as equivalent the counts of yarn and the five qualities specified in equation (4), it is possible to derive the same figures for those years. A straight-line evolution of the quality structure has been assumed to hold throughout the years. However, for the period before 1840 there was no data on the quality of yarn, so it has been assumed that the production of coarse yarn depended on the proportion of functioning hand spindles. This idea is based on technical handbooks and historical

\footnotetext{
${ }^{7}$ The quality $\mathrm{C} 1$ corresponds to yarn below 20 count; the $\mathrm{C} 2$ from 21 to 30 count; the $\mathrm{CF}$ from 31 to 40 count; the F1 from 41 to 60 count; and the F2 from 61 count (all measures are Spanish measures).
} 
data stating that Catalan hand spinners could not produce the finest yarns (Figuerola 1968). Therefore, quality figures from 1830 to 1839 have been constructed by deflating the proportion of coarse yarn to the proportion of production produced by the hand spindles (Rosés 1998).

The former calculations did not consider the process of doubling. This process consisted of doubling the yarn in order the increase its resistance but maintain the count. Note that doubling did not increase the quantity of yarn. Moreover, the doubling process was mainly carried out with fine yarn since doubled yarn was mainly employed in the production of fine cloth and mixed fabrics. Consequently, the relative importance of doubling increased with the increase in the quality of Catalan yarn. For example, in 1840, the doubling process only affected 4 per cent of Catalan yarn (Madoz 1846), while by 1850 this proportion had increased to 14 percent (Ronquillo 1851-1857).

Moving to cotton weaving, the output has been derived from the difference between the total production of yarn and the quantity of yarn employed in mixed fabrics. ${ }^{8}$ The calculation of wastage in weaving is much simpler than in spinning, because the proportion of wastage was the same for all qualities and types of machines. The wastage while weaving was equal to 5 per cent of the yarn employed (Comisión Especial Arancelaria 1867). Moreover, the quality of the cotton cloth relied exclusively on the quality of yarn because coarse yarn could be employed only to produce coarse cloth and, on the contrary, fine yarn could be only employed to produce fine cloth. In other words, the improvements in the quality of cotton cloth were due to the improvements in the quality of yarn produced by the spinning

\footnotetext{
${ }^{8}$ Information on mixed-fabrics production and the origin of yarn derives from Comisión del Gobierno (1841) and Comisión Especial Arancelaria (1867). In Catalonia, high quality mixedfabrics were woven with English fine cotton yarn, while Catalan yarn was used in the production of low-middle quality mixed fabrics. Data due to Madoz (1846) and Figuerola (1968) has been employed to establish yearly figures for the imported English yarn. Finally, the total demand of national yarn by the production of mixed fabrics has been established by assuming that the proportion of high quality mixed fabrics, which were produced with English yarn, and low-middle quality fabrics, which were produced with Catalan yarn, was the same as the figures for 1840 and 1861.
} 
industry. Consequently, each of the five qualities of grey cloth (GC1, GC2, GCF, GF1, GF2) was produced with the equivalent of the five qualities of yarn (C1, C2, CF, F1, F2).

In cotton finishing, the total quantity of output was equal to the quantity of output in weaving since in finishing the wastage was negligible. However, estimating the different categories (qualities) of finishing production generates new problems since quality of finished cloth is partly independent of grey cloth quality. Specifically, the main problem is generated by the fact that not only the finest cloth was printed, but that some coarse cloth was also printed. The solution chosen is to consider five categories of finished cloth: two types of bleached cloth (B1, B2) and three different types of printed cloth (CA1, CA2, CA3). Since the cost of bleaching was the same in B1 and B2, these two kinds of cloth only differed by the grey cloth employed (coarser in B1 than in B2). In printed cloth, the quality CA1 was produced with coarse cloth since it was employed in upholstery and curtains. The quality CA2 corresponds to the calicoes produced with medium grey cloth and a reduced range of colours. The most expensive calicoes (CA3) were produced with the finest quality of grey cloth and printed with several fine colours, and they were employed to produce good quality materials. ${ }^{9}$ Finally, note that the quality of the final production also grew since the proportion of cloth printed grew (for these proportions see Sayró 1842 for 1840, Ronquillo 1851-1857 for 1850, and Gimenez Guited 1862, and Comisión Especial Arancelaria 1867 for 1861).

Considering all the issues mentioned above and the data of the historical sources (Sayró 1842, and Comisión especial arancelaria 1867), the next equation is used to convert grey cloth output into finishing output:

\footnotetext{
${ }^{9}$ Obviously, these three qualities of printed cloth are a necessary simplification of the large range of products produced by the Catalan mills. A complete description of all qualities of Catalan cloth is furnished by Ronquillo (1851-1857) and Orellana (1860).
} 


$$
\begin{aligned}
& \mathrm{B} 1=0.75(\mathrm{GC} 1) \\
& \mathrm{B} 2=0.50(\mathrm{GC} 2) \\
& \mathrm{CA} 1=0.25(\mathrm{GC} 1)+0.50(\mathrm{GC} 2) \\
& \mathrm{CA} 2=(\mathrm{GCF}) \\
& \mathrm{CA} 3=(\mathrm{GF} 1)+(\mathrm{GF} 2) .
\end{aligned}
$$

The last step in the computation of the total value is to establish the prices for each quality of yarn and cotton cloth. However, yearly price data for all qualities of yarn, grey cloth and finished cloth is not readily available. There are only available yearly price figures for the Spanish 30 count of yarn, middle quality grey cloth and cheap calicoes (Diario de Barcelona 1866). It should be noted that these figures seem very accurate according to the different sources contrasted. The main problem with these figures is that they refer to the typical products from the 1850s onwards, but before the 1850s typical Catalan cotton products were coarser. Moreover, it should be taken into account that prices of the different qualities did not evolve in the same way. Therefore, to employ one of these series as a unique deflator could provoke severe distortions in the results. The correct way to solve this data constraint is to construct some kind of superlative price index using a set of prices for all qualities of cotton products available. A Fisher price index was computed for five types of yarn using the 30 count figures as a yearly deflactor and two complete price weights, one by 1840 (Sayró 1842) and one by 1861 (Comisión Especial Arancelaria 1867). The two main advantages of the Fisher price deflator are that the prices reflect technological innovations it is practically equivalent to the Törqvist price index (Diewert 1987). The method used to estimate the prices of grey cloth is similar to the method used with yarn. Two complete price weights for different kinds of cloth and the annual series of grey cloth prices have been employed to construct five different price indices.

The method used to estimate the prices of finished cloth is slightly different to the method used with grey cloth. As with yarn and grey cloth, yearly figures on the prices of cheap calicoes have been used to compute the prices of the three qualities of printed cloth (CA1, CA2 and CA3), with two weights (the weights for 1840 come from Sayró 1842 whereas the weights for 1861 come from Comisión Especial Arancelaria 
1867). However, it is not convenient to employ the prices of printed cloth for estimating the prices of bleached cloth. Since the difference between the two prices is larger, as sometimes calicoes sold for two or three times price of a bleached cloth. Moreover, the technological innovation in bleaching had different chronology to that in calico printing and, hence, the evolution of their prices would diverge. Consequently, the prices of the two qualities of bleached cloth (B1 and B2) have been computed by adding the price of the bleaching process (Comisión especial arancelaria $1867)$ to the prices of grey cloth (GC1 and GC2) as described in Diario de Barcelona (1866).

Once total payments for every year and kind of output has been computed it is simple to compute the final index. The quantities have been estimated previously and the shares of these quantities are the average of the relative values in the $n$ years considered. The exponential of the resulting logarithmic change yields an index number. These indices of sectoral (gross) output for cotton spinning, weaving and finishing are presented in Appendix.

Finally, I construct new indices of sectoral (gross) output for the Catalan cotton industry. According to the definition of sectoral output, the nominal value of sectoral output in the cotton industry is equal to the value of finished cloth production plus the part of spinning production 'exported' to the mixed-fabrics industry. Similarly, the value of grey cloth and yarn employed in the production of 'pure' cotton cloth are not considered, since they are deliveries to purchasers inside the industry. Empirically, the aggregate index is computed as a weighted sum of spinning and finishing sectoral indices, where the weights of spinning and finishing are computed using the value of deliveries to buyers outside the cotton industry. Moreover, other index (which is called a pure quantity index) has been computed. This index is close to the indices developed by other authors. This index is the exponential of the difference of successive logarithms of the actual imports of raw cotton into Catalonia (Motril or foreign), minus a constant wastage of 10 percent. Therefore, it assumes that quality and relative prices remained constant throughout the period. These sectoral output and value-added indices are presented in appendix 1 and figure 1. 
Figure 1. Alternative indices for the Catalan cotton industry, 1830-1861

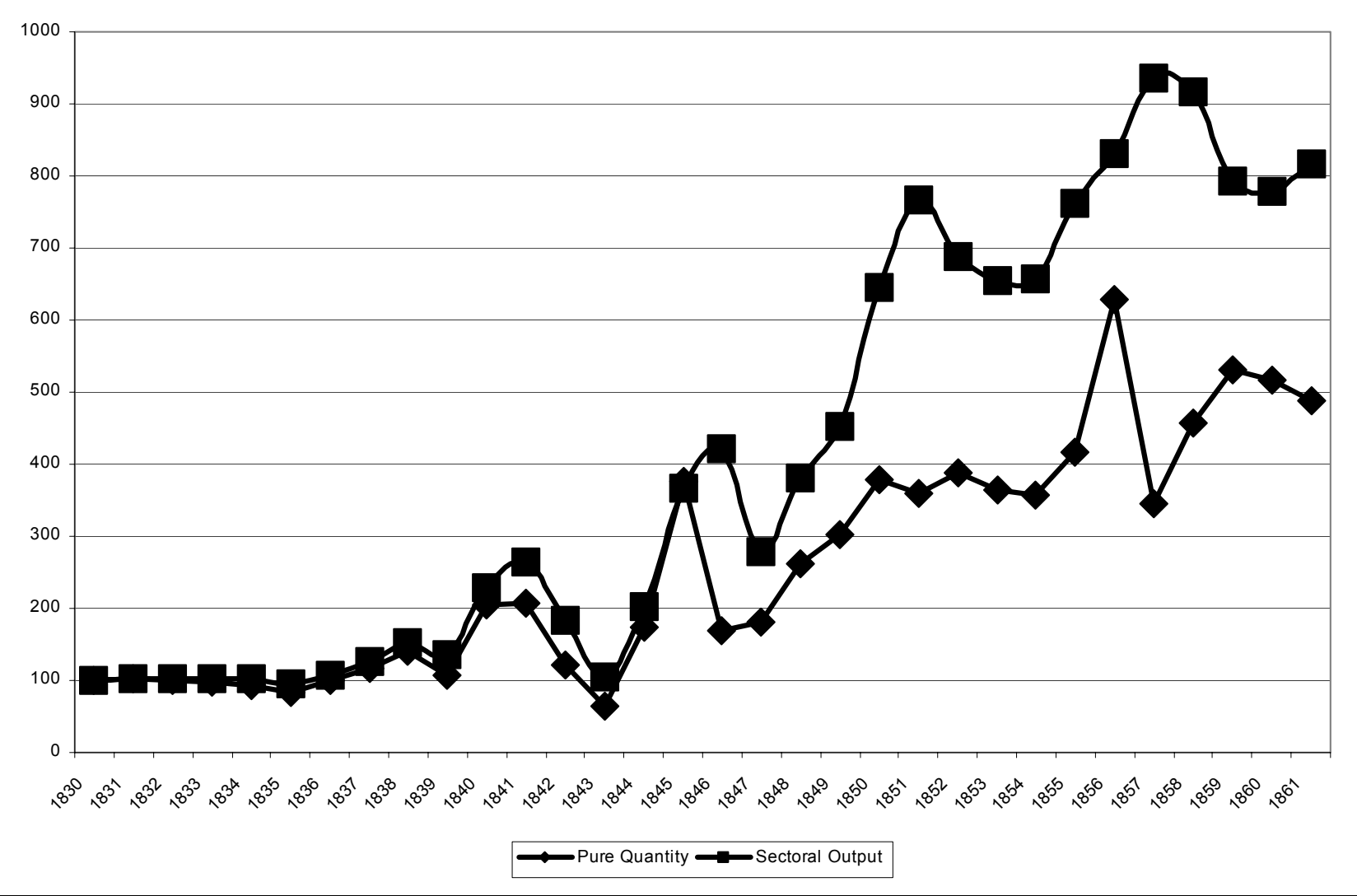

Notes and sources: See text.

The comparison between the two indices is highly revealing. The trend of both indices is practically identical up to 1845 , when quality improvements in the cotton industry were of little importance. Instead, during the remaining fifty years, the new sectoral output index moves faster than the pure quantity (traditional) index. Undoubtedly, this result serves to underline the importance of quality change in explaining the evolution of Catalan cotton industry.

\section{Catalan Manufacturing Output (1840-1861)}

The goal of this section is to generate new measures of the growth of Catalan manufacturing from 1840 to 1861 . Specifically, it has been developed measures of real sectoral (gross) output, physical intermediate inputs and value-added for nine Catalan industries and an aggregate measure for modern manufacturing. 
Output data on current values for two benchmark years (1840 and 1861) is available for nine industries. In the paper, metal, and mixed fabrics industries output values are taken from the sources. ${ }^{10}$ The values of cotton industry (spinning, weaving and finishing) output are those computed in the previous section. Finally, the values of the wool, linen and silk industries have been estimated from several sources.

For the wool industry in 1840, the quantity and current value of production was computed using raw wool figures. The quantity of raw wool employed by the wool industry is equal to the quantity of raw wool imported into Catalonia $(300,000$ arrobas) minus the quantity of raw wool employed by mixed fabrics (21,570 arrobas). The quantity of raw wool is from Benaül (1991, pp.119) and the mixed fabrics data comes from Sayró (1842). Since, at that time, six arrobas of raw wool were necessary to produce one wool fabric (Benaül 1991, pp. 119), which had on average 40 varas castellanas, and the average price was Pta. 2.5 per vara (Figuerola 1968, pp. 225), the current value of the production was Pta. 4,640,500. ${ }^{11}$

For silk and linen, the methodology differs slightly from that employed for wool. As for wool, the quantity of fibre (silk in hanks and linen yarn respectively) consumed by the silk and linen industries is equal to the quantity imported into Catalonia, minus the quantities consumed by mixed fabrics production and lost in wastage. The imports of silk amounted 67,000 kg. (Figuerola 1968, pp. 226) but 7,000

10 The sources are in 1840: for the metal and mixed fabrics industries Sayró (1842) and Madoz (1846); and for the paper industry Delgado (1991), pp. 214 and Gutierrez (1837). Instead, the 1861 data for all industries comes from Gimenez Guited (1862).

${ }^{11}$ A test of the quality of the result can be obtained by computing the implicit density (kg./m.) of the average fabric and comparing this result with the data that appeared in the contemporary technical handbooks. Density can be calculated by multiply raw wool by 0.4 (eliminating the wastage in the process of cleaning), then by 0.95 (eliminating the wastage in the process of spinning), and then dividing by the number of fabrics multiplied by 33.4 (the measure in metres of 40 varas). The implicit density was $0.7858 \mathrm{~kg} . / \mathrm{m}$. whereas the technical handbooks show that the densities of wool fabrics produced in Catalonia were in the range of 0.55 to $0.95 \mathrm{~kg} . / \mathrm{m}$. (see Ronquillo 1851-1857, pp. 373-385). The wastage of raw wool is based on the coefficient of Prados de la Escosura (1983), pp. 469. 
kg. were used in the production of mixed fabrics (Sayró 1842). In the case of linen, the imports of linen yarn amounted to $142,540 \mathrm{~kg}$. (Madoz 1846, pp. 555) and 41,675 $\mathrm{kg}$. were consumed by mixed fabrics (Sayró 1842). Since the prices of cloth are only available in varas, it has been necessary to compute the quantity of varas produced. ${ }^{12}$ The quantity of varas is computed in two steps: first the weight of cloth is obtained, deleting the wastage through weaving from the quantity of yarn and, then, the resulting figure is multiplied by the average density of the cloth. ${ }^{13}$ Then, the value of output is the quantity of varas multiplied by its average price. Finally, for 1861, the value of output in silk, linen and wool is taking directly from the source (Gimenez Guited 1862, pp. 210-212), but before using the figure one must first subtract the quantities sold to the mixed fabrics industry and to remove yarn from the total value. This is possible since the source gives the quantities of yarn and cloth produced.

A further problem is that Gimenez Guited's guide included a lot mixed fabrics production within the production of the silk, wool and linen industries. Furthermore, many weavers, especially those that wove with jacquard looms, changed textile fibre (even two or three times during the year) according to the changes in fashion and season (Comisión Especial Arancelaria 1867, and Cerdá 1968). For example, during summer, they produced winter textiles with wool, or blended wool with cotton or silk, while in the winter they produced summer textiles with linen, silk or/and cotton. In other words, it does not seem justifiable to separate the different non-cotton textile sectors and, therefore, all these industries are put together in a single measure.

The values of intermediate inputs were also estimated. Sources only provided the value of all inputs in the metal (Madoz 1846, and Figuerola 1968), mixed fabrics (Sayró 1842), linen (Madoz 1846) and paper (Gutiérrez 1837) industries for 1840. Therefore, all the values for 1861 and the rest of the values for 1840 have been estimated from the available cost functions and/or the quantities consumed of the

\footnotetext{
${ }^{12}$ In particular, the average price of silk cloth per vara was $25 \mathrm{Rv}$, whereas the price of linen cloth was $6 \mathrm{Rv}$ (the first number from Figuerola 1968, pp. 224-225 and the second from Madoz 1846, pp. 555). The wastage of silk and linen is based on the coefficients of Prados de la Escosura (1983), pp. 470-471.

${ }^{13}$ The average densities were $0.14205 \mathrm{~kg} . / \mathrm{vara}$ for silk and $0.1492 \mathrm{~kg}$./vara for linen (these
} 
main inputs. Specifically, the quantities of raw fibre consumed were used to estimate values of inputs for wool and silk in $1840 .{ }^{14}$ In the metal, linen, mixed fabrics, silk and wool industries, detailed cost functions are available and they have been used to compute the values of inputs for 1861 (the sources of these cost functions are Ronquillo 1851-1857, Comisión especial arancelaria 1867, and Escribano 1986).

In cotton spinning, the quantity of raw cotton is drawn from the figures described in the above section 2, while the price figures for each type of raw cotton are drawn from Izard (1969). However, the price of the raw cotton from Motril and Puerto Rico is assumed equal to the price of Brazilian raw cotton, which is most similar in terms of quality. The rest of the intermediate inputs in spinning have also been estimated using for 1840 the information furnished by Comisión del Gobierno (1841), and for 1861 the evidence collected by Comisión Especial Arancelaria (1867).

In cotton weaving, the main input was, obviously, the yarn, for which the complete figures have already been used for the spinning calculations. Next, the amount of Catalan yarn employed to produce mixed fabrics instead of pure cotton cloth was computed and the figure obtained has been subtracted from the total yarn figures. Finally, as in spinning, the costs and weights of the remaining intermediate inputs were calculated with Sayró (1842), and Comisión especial arancelaria (1867) data.

Moving to cotton finishing, the main input was grey cloth, for which the complete figures were already given for weaving. Then, the consumption of energy, chemical and colouring products during the process of finishing cloth was computed using the same sources employed in cotton weaving. It should be underlined that to produce each kind of finished cloth different quantities and types of inputs were employed. Thus, the evolution in the consumption of different inputs is related to the changes in the composition of finished cloth production. For example, to produce finest calicoes with several colours, printers had to employ more energy and colour

densities are an average of the data of Ronquillo 1851-57, pp. 385-389 and 394-409).

${ }^{14}$ It should be noted that in 1840 in both industries all machinery was hand-powered and that the other costs of production, except transport that is included in the price of raw materials, were relatively small. 
than to produce coarse calicoes. Table 1 reports the evidence on the values of industrial output and inputs at current prices.

Table 1. Sectoral Output and Intermediate Inputs:

Modern Industries, 1840-61 (current prices, thousand Pta.)

\begin{tabular}{lrrrr}
\hline & \multicolumn{2}{c}{ Sectoral Output } & \multicolumn{2}{c}{ Intermediate inputs } \\
& 1840 & 1861 & 1840 & 1861 \\
\hline Cotton Spinning & 31,592 & 67,422 & 17,356 & 48,094 \\
Cotton Weaving & 46,419 & 93,758 & 28,005 & 68,560 \\
Cotton Finishing & 76,597 & 143,296 & 53,309 & 106,480 \\
Cotton Industry & 80,484 & 147,519 & 22,192 & 62,393 \\
Metal Industry & 2,402 & 8,703 & 1,941 & 4,666 \\
Other textiles & 43,656 & 92,040 & 29,794 & 60,031 \\
Paper Industry & 5.250 & 6.366 & 2.007 & 2.844 \\
\hline
\end{tabular}

Notes and sources: See text. Cotton industry sectoral output is here the aggregation of

finishing sectoral output value and the cotton yarn sold to mixed fabrics industry.

Given the measures of outputs and intermediate inputs in current prices, the next task is to separate this data into price and quantity components, the real sectoral output. The traditional method is to separate components using deflators. Here, the deflators are Divisia (Törqvist) price indices ${ }^{15}$, which have been computed according to the next equation:

$$
\ln P_{t}-\ln P_{t-1}=\sum_{i}\left[\bar{\Theta}_{P_{i}}\left(\ln p_{i_{t}}-\ln p_{i_{t-1}}\right)\right]
$$

where pi designates prices, and $n$ prices (1..i..n) are being considered. The two time periods are $t$ and $t-1$, and the value share weights $\Theta_{x i}$ are computed as:

$$
\begin{gathered}
\bar{\Theta}_{P_{i}}=1 / 2\left[\theta_{p i}(T)+\theta_{p i}(T-1)\right], \\
(i=1, . . i, . . n) .
\end{gathered}
$$

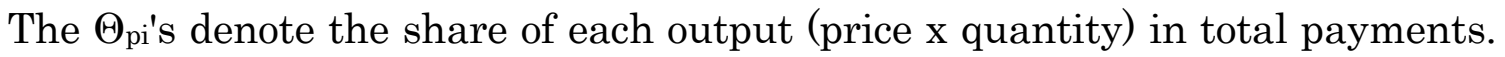
The exponential of this logarithmic change generates an index number.

15 However, when the information is sparse the deflators of the main product of the industry have been used. It should be noted that these deflators are equivalent to Divisia deflators if the product considered is the average product of the industry. See Hill (1993). 
Measures computed by deflating current values with Törqvist price indices are equivalent to the measures computed with Törqvist quantity indices (Hill 1993, pp. 384). Consequently, they avoid the problems related to the fact that some Catalan industries changed substantially the quality of products during this period and/or in the composition of the physical inputs. ${ }^{16}$

Törqvist deflators are constructed for outputs and inputs for each industry, except the paper industry's inputs, where the deflator is the index of wholesale prices computed by Sardà (1948). Up to six categories of inputs has been considered in cotton spinning, weaving and finishing (for outputs see section 2). In spinning the six categories of inputs are: five types of raw cotton and rest of materials (mainly coal); in weaving, the five types of yarn and rest of materials (mainly, again, coal); and in finishing, the five types of grey cloth, coal, and chemical materials for bleaching or printing. In the metal industry, the prices of inputs correspond to the prices of iron ingot and coal. Output prices are for metal plate and steam engines. For the input deflator the weights are: 90 percent iron ingot, 10 percent for coal. ${ }^{17}$ For the output deflator metal plate and steam engines have equal weighting. In the paper industry the price of output corresponds to the price of common paper, while the price of inputs is computed with the Sardà (1948) wholesale index.

The most formidable problems arise in the construction of price indices for the remaining textiles, especially for outputs. Specifically, in outputs the main problem was to convert many different measures into an equivalent unit of weight. Then after

\footnotetext{
${ }^{16}$ It should be noted that in this kind of situation alternative Laspeyres, Paasche or unitvalue deflators tend to bias the results. For example, the cotton spinning industry modified the composition of its output towards more quality yarn, thus increasing the proportion of input costs that were due to energy use. Therefore, a unit-value deflator tends to artificially increase the price of outputs and decrease the price of inputs.

${ }^{17}$ In particular, the prices are: coal 5.5945 Pta/Qm (1840) and 5.875 Pta/Qm (1861), iron ingot 21.13 Pta/Qm (1840) and 23.64 Pta/Qm (1861), for iron plates $88.76 \mathrm{Pta} / \mathrm{Qm}$ (1840) and 80.5 Pta/Qm (1861), steam engines of low pressure (below 25 h.p.) are $1500 \mathrm{Pta} / \mathrm{h} . p$. (1840) and $1240 \mathrm{Pta} / \mathrm{h} . p$. in 1861. The prices for 1840 come from Sayró (1842), except the price of steam engines which comes from Figuerola (1968) whereas the prices for 1861 came from Comisión Especial Arancelaria (1867).
} 
this one must construct coherent output categories. To convert the unit that appeared in the 1840 sources, varas castellanas (a length unit equivalent to 0.835 metres), to the weight unit of 1861 (kg.), it must be obtained the density of each kind of cloth and then multiply by the 1840 data. It should be noted that another problem is caused by the fact that different types of cloth had different widths, and hence densities per vara not only change due to weight but due to width. Ronquillo collected data on all kinds of cloth produced in Catalonia and their standard weight and densities (Ronquillo 1851-1857, pp. 344-414). ${ }^{18}$ Cautiously, prices of clothes that have altered their composition or quality have been avoided. For example, some kinds of mixed fabrics reduced the quantity of cotton yarn increasing, in turn, the quantity of the other textiles fibres during the period. ${ }^{19}$

Table 2 reports price indices constructed using equation 6 for sectoral output and intermediate inputs. Perhaps the most striking pattern that emerges from a comparison between the output and input price indices is that the prices of outputs declined significantly relative to those of inputs.

${ }^{18}$ In the case of several weights and densities I decided to take an average of the available data.

${ }^{19}$ In particular, the prices of inputs are: Low-quality washed Raw Wool (Spanish): 1.79 (1840), 2.24 (1861); High-quality washed Raw Wool (Spanish): 6.51 (1840), 7.66 (1861); Imported wool yarn (French, count no. 80): 9.77 (1840), 13.2 (1861); Linen white yarn (Imported): 3.75 (1840), 5.48 (1861); Silk yarn in hanks (Spanish): 48.86 (1840), 45.48 (1861); Cotton yarn (Catalan, count no. 59): 11.8 (1840), 8.58 (1861); Imported cotton yarn (English, count no. 80): 20.63(1840), 16.13 (1861). Imported Coal (British): 5.43(1840), 5.87 (1861). The price of Outputs are: Damasco de lana (pure wool cloth): 19.43 (1840), 16.45 (1861); Raso de seda (fine silk cloth): 95.55(1840), 83.56; Cutíes (pure linen cloth): 14.24(1840), 10.82 (1861); Dril (linen and cotton cloth) 13.24 (1840), 14.85 (1861); Telas para vestidos (cheap wool and cotton cloth): 23.19(1840), 19.37 (1861); Pañoleria de Invierno (fine wool and cotton cloth): 36.8 (1840), 30.53 (1861); Damasco de mezcla (fine wool and cotton cloth): 25.62 (1840), 19.23 (1861). All prices are in Pta /kg. except coal that is in Pta/Qm. and are prices in Barcelona's market. The prices of 1840 from Sayró (1842) except linen white yarn from Madoz (1846) and the prices of 1861 from Comision especial arancelaria (1867). The price of high-quality raw wool is an average of the price of Extremeña superior and Aragonesa superior. 
Table 2. Price Indices of Sectoral Output and Intermediate Inputs:

Modern Industries, $1861(1840=100)$

\begin{tabular}{lrr}
\hline & $\begin{array}{c}\text { Sectoral } \\
\text { Output }\end{array}$ & \multicolumn{2}{c}{$\begin{array}{r}\text { Intermediate } \\
\text { Inputs }\end{array}$} \\
\hline Cotton Spinning & 69.82 & 112.49 \\
Cotton Weaving & 56.81 & 72.46 \\
Cotton Finishing & 53.58 & 63.73 \\
Cotton Industry & 54.21 & 105.8 \\
Metal Industry & 86.59 & 111.37 \\
Other textiles & 85.77 & 107.91 \\
Paper Industry & 78.49 & 116.98 \\
\hline
\end{tabular}

Notes and sources: See text.

Once the sectoral output and intermediate sectoral inputs indices were constructed, it was possible to develop value-added indices for each sector. The rate of growth of sectoral value-added can be expressed in terms of growth rates of intermediate input and output and the average value shares:

$$
\left.\ln V A_{t}-\ln V A_{t-1}=\frac{1}{\bar{\Theta}_{X_{i}}}\left(\ln x_{i_{t}}-\ln x_{i_{t-1}}\right)-\frac{\bar{\Theta}_{Y_{i}}}{\bar{\Theta}_{X_{i}}}\left(\ln y i_{t}-\ln y i_{t-1}\right)\right]
$$

where VA designates value-added, $\mathrm{x}$ sectoral (gross) outputs and $\mathrm{y}$ sectoral intermediate inputs, where $\mathrm{n}$ outputs and inputs (1..i...n) are being considered. Two time periods are $\mathrm{t}$ and $\mathrm{t}-1$, and the value share weights $\Theta_{\mathrm{xi}}$ are computed as:

$$
\begin{gathered}
\bar{\Theta}_{X_{i}}=1 / 2\left[\theta_{x i}(T)+\theta_{x i}(T-1)\right], \\
(i=1, . . i, . . n) .
\end{gathered}
$$

where the $\Theta_{x i}$ 's denote the share of each output (total payments) in its sectoral output. Similarly, the $\Theta_{y i}$ 's denote the share of each input (total payments) in sectoral output. The next table presents estimates of growth rates of sectoral output, intermediate inputs, its share in total payments, and value-added. 
Table 3. Growth Rates (yearly percent) of Sectoral Output and Value-added: Modern Industries, 1840-1861

\begin{tabular}{|c|c|c|c|c|}
\hline & $\begin{array}{l}\text { Sectoral } \\
\text { Output }\end{array}$ & $\begin{array}{l}\text { Intermediate } \\
\text { Inputs }\end{array}$ & $\begin{array}{c}\text { Share } \\
\text { Intermediate }\end{array}$ & $\begin{array}{l}\text { Value } \\
\text { Added }\end{array}$ \\
\hline Cotton Spinning & 5.32 & 4.29 & 0.63 & 7.07 \\
\hline Cotton Weaving & 6.04 & 5.8 & 0.67 & 6.53 \\
\hline Cotton Finishing & 5.95 & 5.44 & 0.72 & 7.26 \\
\hline Cotton Industry & 5.8 & 4.65 & 0.35 & 6.42 \\
\hline Metal Industry & 6.82 & 3.66 & 0.67 & 13.24 \\
\hline Other textiles & 4.28 & 2.97 & 0.67 & 6.94 \\
\hline Paper Industry & 2.07 & 0.91 & 0.41 & 2.88 \\
\hline
\end{tabular}

Notes and sources: See text for methods and sources.

To aggregate single measures into sectoral gross output and value-added figures, the methodology developed by Jorgenson (1990) has been used. Two kinds of aggregation have been developed. The first is a weighted average of the individual industries' sectoral output, intermediate inputs and value-added, with weights given by the current values. The second has been developed under the assumption of separability of value-added and the existence of an aggregate function for the whole industry. Therefore, current values of sectoral output, intermediate inputs and the corresponding (Törqvist) price indices were computed. The results are presented in the table below:

Table 4. Growth rates of Aggregate Sectoral Output, Intermediate Inputs and Value-added: Modern Industries, 1840-61 (percent per year)

\begin{tabular}{lccc}
\hline & $\begin{array}{c}\text { Sectoral } \\
\text { Output }\end{array}$ & $\begin{array}{c}\text { Intermediate } \\
\text { Inputs }\end{array}$ & Value-added \\
\hline Weighted sum & 5.29 & 3.68 & 6.54 \\
Aggregate model & 5.13 & 3.72 & 6.30 \\
\hline
\end{tabular}

Notes and sources: see text.

It should be noted that the difference between the first model and the second model is, according to Jorgenson, the result of market failures and, consequently, to the misallocation of resources. Traditionally, economic historians have preferred the first version (see, for example, Crafts 1985, pp. 27-28 and Prados de la Escosura 
1988, pp. 163).

\section{The Role of the Catalan industry in the Growth of Spain}

In the two previous sections, new measures of output and value-added for several Catalan industries have been developed. The next table aids the comparison of previous estimates for Catalonia and Spain with the new figures:

Table 5. Alternative Industrial Indices: Catalonia and Spain (1830-1861)

\begin{tabular}{|c|c|}
\hline & Yearly Growth Rates \\
\hline \multicolumn{2}{|l|}{ Catalonia } \\
\hline Maluquer de Motes (1840-1861) & 5.28 percent \\
\hline Carreras (1844-1861) & 6.20 percent \\
\hline New Estimates (1840-1861) & $5.13-5.29$ percent \\
\hline \multicolumn{2}{|l|}{ Spain } \\
\hline Carreras (1830-1861) & 4.60 percent \\
\hline Prados de la Escosura (1830-1861) & 2.32-2.64 percent \\
\hline
\end{tabular}

Notes and sources: Catalonia: Maluquer (1994), pp. 70, Carreras (1990), pp.56; New estimates: sectoral output in previous table 4. Spain: Carreras (1990), Prados de la Escosura (1988), pp. 166.

It is immediately apparent from table 5 that the difference between the new and the previous industrial output estimates for Catalonia is relatively small. With the early Carreras's index about one point, with the more recent Maluquer's index the difference is negligible. The comparison of the evolution of the Catalan index with the Spanish indices is also very revealing. Any indicator shows that Catalan industrial growth rates were almost 30 percent higher than Spanish rates.

In spite of these small differences in growth rates, in each study on Catalan industry the contribution of their sub-components is different. Thus, in Carreras's index the cotton industry explained about 77 percent of Catalan growth in 1860. In Maluquer's index (Maluquer 1994, pp. 59), the proportions vary from a minimum of about 40 percent to a maximum of about 49 percent. This study puts the proportion 
at around 67 percent. It is clear that some discussion of the causes is required. ${ }^{20}$

The growth rates of the new quantity indices of the cotton industry, which were computed with the Törqvist formula, are higher than those estimated by Maluquer and Carreras. The reason is simple since the Törqvist indices consider quality shifts in the composition of sectoral output. This is shown in Figure 1 where the 'pure quantity index' moves slower than the Törqvist index. More specifically, the quantity index has a yearly growth rate of 5.12 percent whereas the new sectoral output index experiences a growth rate of 6.77 percent. Since this study's estimate of the rate of growth of the cotton industry is higher than the estimates of Maluquer and Carreras, we should infer that the other industries had lower growth rates in this study. However, these lower growth rates cannot be attributable to the particular treatment of index numbers in the paper since there were output quality increases in the metal, linen, silk, and mixed fabric industries. Consequently, one may confidentially suppose that the difference is related to the treatment of the mixed fabrics industry, which is taken into account in this study. Instead, Carreras and Maluquer assume that all cotton yarn is used for the production of pure cotton cloth and, hence, do not considered mixed fabrics as a separated industry. This fact is certainly relevant given that Catalan cotton industry grew at the expenses of mixed fabrics industry and mixed textiles had higher value added per unit of weight than cotton textiles.

On a less optimistic note, however, one can argue that the sample used for the new index is biased in favour of the modern and capital-intensive industries, and is biased against the traditional (and slow-growth) sectors. Note that a characteristic of the Catalan secondary sector was its capability to produce many different industrial goods. For example, in 1861, Gimenez Guited collected data on 13 major industries located in Catalonia (cotton, olive oil refining, flour, wool, silk, soap manufacturing, spirits and liquors distilling, linen, metal manufacturing, paper, mixed fabrics, curtains and cork). On this sense, the industries in the index had about 85 percent of workers and 92 percent of the capital of the industries located in Catalonia by

\footnotetext{
${ }^{20}$ It should be noted, however, that it is impossible to compare this paper's weights with the weights of the other authors since they do not provide enough information on this aspect.
} 
Gimenez Guited. ${ }^{21}$ Furthermore, other minor industries such as bakery, beer brewing, card-making, chemical products, gloves, jewellery, pottery, shoemaking, woodwork and furniture, glass, hosiery, boatyards, quarries, publishing, clothing, pin-making, wax, wine, hat manufacturing, canning, and coaches were also located in Catalonia. ${ }^{22}$ Therefore, it seems necessary to compute the coverage of the sample in order to determine the bias introduced by measuring only the modern sectors and paper.

This can be done with value-added figures. The first step is to compare the value-added figures for Catalonia and Spain. According to Nadal, in 1856 Catalonia paid 25.04 of Spanish manufacturing tax. ${ }^{23}$ Considering that the Basque Provinces and Navarre did not pay direct taxes and that they must represent about 10.25 percent of the Spanish manufacturing, ${ }^{24}$ Catalonia might possess about 22.5 percent

${ }^{21}$ Gimenez Guited (1862), pp. 207-214

${ }^{22}$ See the references to these industries in Madoz (1846) and Cerdà (1968).

${ }^{23}$ Taxes for manufacturing and mining were paid separately and it is likely that mining taxes were higher than manufacturing ones. For example, in 1856, manufacturing taxes amounted about 2.4 million Pta whereas mining taxes amounted about 1.2 million Pta (Nadal (1992a), pp.156). If the taxes were set according to value-added then one could infer that mining produced about one third of Spanish industrial value-added. However, Mulhall (Prados de la Escosura (1982), p 110) assigned to mining a value 125 million of Pta, around 11.4 percent of total Spanish industry value-added. Furthermore, Prados de la Escosura in his index gives mining share of industrial value-added of only 5.1 percent, whereas Carreras gives it share of 14.6 percent (Prados de la Escosura (1988) and Carreras (1990b), pp. 91). To sum up, to establish the share of mining in industrial value-added, taxes must not be used.

24 In 1861 the Basque and Navarre Provinces had the following shares in several industries: 7.5 percent in flour, 5.1 percent in olive oil refining, 20.5 percent in cotton spinning, 16.9 in cotton weaving, 21.4 percent in calico printing, 2.0 percent in wool spinning, 7.8 percent in wool weaving, 12.5 percent in silk spinning, 13.3 percent in paper, 13.8 percent in leather, 13.9 in linen, 12.5 percent in soap and 10.3 percent in spirits. (Source: Gimenez Guited (1862), pp. 207-214). From this data we can infer several industry shares: 7.5 percent in food, 14 percent in textiles, 20 percent in metal, 12 percent in chemicals, 14 percent in leather and 13 percent in paper. Then, with the value-added shares of Prados de la Escosura (1988), pp. 163 it can be established their share in Spanish manufacturing was 10.25 percent. 
of Spanish manufacturing. Prados de la Escosura, after correcting Mulhall's previous figures, estimated the current value of the value-added of the Spanish manufacturing production as 975 million of $\mathrm{Pta}$ in $1860 .{ }^{25}$ Therefore, the total value-added of Catalan manufacturing was about 219.4 million Pta, whereas the value-added of the sample is 124.7 million Pta (i.e., about the 56.8 percent of the value-added of Catalan manufacturing).

The next step consists of computing a range of possible estimates of Catalan industry growth rates for the industries where there was no data. Empirically, the overall growth rate is equal to the growth rate of the modern industries multiplied by their share in value-added (which was about 56.8 percent) plus the growth rate of the non-represented industries (traditional sectors) multiplied by their share in valueadded (which was $100-56.8=43.2$ ). It seems plausible that the growth rates of the traditional sectors were positive but did not exceed the growth rates of the modern sectors. Therefore, their growth rates were between 0 and 5.29 percent per year. Then, resulting overall industry growth rates might be (in the case of zero growth in traditional sectors) between 3 percent and 5.29 percent per year (in the case of the same rates in modern and traditional industries). Therefore, one can confidentially suppose that early industrialisation significantly increased overall industry growth rates, even if traditional sectors remained stagnant.

Using this range of estimates of Catalan industry, one can also estimate the contribution of Catalan industry to the growth of Catalan GDP and Spanish GDP. Specifically, the contribution of Catalan industry is the result of multiplying each estimate by the share of Catalan industry and then dividing the result by the overall growth rates. Since the calculations employ value-added weights that corresponded to the last year the results are equivalent to a Laspeyres index and, hence, overstate the Catalan contribution to Spanish growth rates. Moreover, the results may be biased because it is likely that this revision of Catalan industry output altered Spanish figures by a significant amount. Therefore, in order to correctly establish the contribution of Catalan industry to Catalan and Spanish growth rates, industrial output and GDP estimates for Spain should be revised to include the new

${ }^{25}$ Prados de la Escosura (1982), pp. 110. 
estimations.

The share of the value-added of Catalan industry in Catalan and Spanish GDP can be estimated by means of Mulhall's figures. ${ }^{26}$ Carreras and Yáñez give the share of Catalonia in Spanish GDP as 13.4 percent in $1862 .{ }^{27}$ Then, since the current value Spanish GDP was of 5,594 million Pta in 1860, and assuming the same proportion for 1862 and 1860, the Catalan GDP was 749.6 million Pta. ${ }^{28}$ In other words, the share of value-added of Catalan industry was equal to 29.3 percent of Catalan GDP and 3.9 percent of the Spanish GDP. ${ }^{29}$

The data on Catalan GDP are imperfect and so any estimates are controlled conjectures and, hence, the choice is to estimate two alternative figures for Catalan GDP. The first (GDP A) is based on the assumption that the share of Catalonia in Spanish GDP in 1832 was the same as in 1802 (8.3 percent). ${ }^{30}$ The second (GDP B) has been computed under the assumption that the portion of Catalonia in the Spanish GDP in 1832 was the geometric average of the quotas of 1802 and 1860 (the share in 1860 was 13.3 percent). ${ }^{31}$ The rate of growth resulting with GDP A (2.57 percent per year) is the upper bound, and the rate of growth of GDP B is the lower bound (1.62 percent per year). The choice of GDP has strong implications for the interpretation of the period from 1830 to 1861 and the previous phase from 1802 to 1830. Specifically, with GDP A Catalonia grew during the period 1800-1830 at the

${ }^{26}$ Prados de la Escosura (1982), pp. 110.

${ }^{27}$ Carreras and Yañez (1992), pp. 156.

${ }^{28}$ It should be noted that the discrepancy between this estimate and that provided by Carreras and Yañez is because they computed Spanish GDP as 7,071 million Pta and Catalan GDP as 948 million Pta (Carreras and Yañez (1992), pp. 156). However, the choice is not to modify Prados de la Escosura' figures since he separates Spanish GDP into its different components.

${ }^{29}$ Similarly, since the value-added of Spanish industry (i.e., manufacturing plus mining) was 1,100 million Pta in 1860 (Prados de la Escosura (1982), pp.110), the share of Catalonia was about 19.9 percent.

30 Sources: Spanish GDP, Prados de la Escosura (1982), pp. 110 and Catalan shares Carreras and Yañez (1992), pp. 157.

${ }^{31}$ The same sources as in previous footnote. 
same rate as Spain (a mere 0.31 percent per year) whereas with GDP B it grew at four times the Spanish rate (1.23 percent per year). By contrast, during the following period (1830-60), with GDP A Catalan growth was double the Spanish growth rate, whereas with GDP B grew at only a quarter faster than the rest of Spain. Demographic figures revealed that from 1800 to 1830 the Catalan experience was very similar to the rest of Spain, whereas in the 1830-1860 the growth rates of the Catalan population were double the Spanish average. ${ }^{32}$ According to Pérez Moreda, Catalonia suffered during this period 'a precocious and striking decline in mortality as well as immigration from other regions.' ${ }^{33}$ Admittedly, the estimates of the Catalan experience derived from GDP B is unlikely, but it would be desirable to expand our knowledge of the first third of the nineteenth century to discriminate definitively between both figures.

Finally, it is worth to revise previous estimates on Spanish industrial production, considering the new growth rates. ${ }^{34}$ It is of interest to note that the industries considered in this sample were the Catalan industries with larger shares in Spanish industry. An estimate based on the Gimenez Guited data suggests that Catalonia had 69.1 percent of the textile industry, 17.4 percent of the metal industry and 30.8 percent of the paper industry. ${ }^{35}$ By contrast, the share of the rest of the Catalan industries in Spanish value-added was reduced, except in cork manufacturing (a very small industry). ${ }^{36}$ Consequently, one can conjecture that their

${ }^{32}$ In particular, the average annual demographic growth rates per thousand habitants in the period 1797-1833 was 4.3 in Spain and 5.4 in Catalonia, whereas in the next period (1834-1857) 9.6 in Spain and 19.4 in Catalonia (Pérez Moreda (1987), Table 2.3, pp. 18).

${ }^{33}$ Pérez Moreda (1987), pp. 19.

${ }^{34}$ I cannot recalculate Carreras' index since in his book (Carreras, (1990b) the industrial index is not disaggregated by sub-sectors.

${ }^{35}$ Based on industrial tax (1856), Nadal reports similar figures: 66.3 percent in textiles, 21 percent in metal and 31.8 percent in paper (Nadal (1992a), pp. 153).

${ }^{36}$ According to Nadal (1992a), pp. 153, 10.1 percent in food and drink, 15.7 percent in construction goods, 13.3 percent in leather, 17.4 percent in chemicals, 24.5 percent in wood and furniture, and the exceptional 42.8 percent in miscellaneous industries (mainly cork manufacturing). 
growth rates did not affect total growth rates. Furthermore, since Prados de la Escosura does not consider the paper industry in his estimates, we only need to modify the growth rates of the metal and textile industries.

One can also introduce a further refinement to Prados de la Escosura' index by re-weighting the textile industries. Similar to the debate on the British Industrial Revolution, the debate on the early phase of Spanish industrialisation was centred on the appropriate weights that must be given to the different industries. Two main issues have been raised by Carreras and Prados de la Escosura, the quotas of the two main sectors, food and drink and textiles, and the share of the cotton industry within textiles. ${ }^{37}$ Indeed, the results are very sensitive to the weighting for cotton. The great advantage of this sector is the availability of good historical data (this assertion is supported the second and third sections of this paper). Furthermore, Gimenez Guited calculated precisely the output of all the textile industries (cotton, wool, linen, silk and mixed fabrics), except the clothing industry, for all Spain, including the Basque and Navarre provinces. Therefore, employing this data and the production functions available, it is simple to compute the current value-added of the textile industries. These current values can then be weighted with the total current values given by Mulhall to obtain their share into Spanish GDP. ${ }^{38}$

Table 6. Share (percent) of the Textile Industries:

${ }^{37}$ Carreras employed a backward extrapolation of the ratio between the value-added at factor costs and the value of total product in 1958, which was the first year in which highly reliable Spanish National Accounts data was available. Carreras also used a unique price vector for the whole cotton industry to determine the value-added share to total industrial production. In contrast, Prados de la Escosura used the shares of each industry in the industrial tax records (Contribución industrial y de comercio) for 1856 and 1900, under the assumption that these corresponded well to the value-added. See the criticism of the methodologies in: Prados de la Escosura (1988) chapter 4 and Carreras (1990b), addenda to chapter 3 .

${ }^{38}$ Note that the shares computed with this method are not directly comparable with the shares computed by other authors since their indices were based on a sample of industrial activity rather than data for the whole sector. 
Spanish Industry Value-added, 1860

\begin{tabular}{lrrrrrr}
\hline & \multicolumn{3}{c}{ Share in total value-added } & \multicolumn{3}{c}{ Share in textile industries } \\
& Carreras & Prados & New & Carreras & Prados & New \\
\hline Cotton & 27 & 8 & 11.6 & 78.7 & 34.8 & 56.9 \\
Wool & 2.7 & 12.4 & 4.5 & 7.9 & 53.9 & 22.1 \\
Linen & 4 & 1.9 & 2.5 & 11.7 & 8.3 & 12.2 \\
Silk & 0.6 & 0.7 & 1.1 & 1.7 & 3 & 5.4 \\
Mixed fabrics & & & 0.7 & & & 3.4 \\
Total & 34.3 & 23 & 20.4 & 100 & 100 & 100 \\
\hline
\end{tabular}

Notes and sources: Carreras and Prados de la Escosura figures came from Carreras (1990b), pp. 91. The new estimates are derived from Gimenez Guited data ((1862), pp. 209-212). The share in the total values added is the result of to divide the value-added of each industry by Mulhall estimate on industrial value-added modified by the same Prados de la Escosura (Prados de la Escosura (1982), pp. 110).

Prima facie, the new estimates are relatively closer to Prados de la Escosura' than Carreras' figures. In this study, the share of output of the textile industries is smaller than the share assigned by Prados de la Escosura and Carreras. However, it should be noted that the total share of the textile industry in the new estimates is probably the lower bound of the sector, since clothing has been not considered. Due to this, it seem unnecessary to modify the quota of the textile industry (23 percent) given by Prados de la Escosura. ${ }^{39}$ However, the composition of this new estimate for textiles differs greatly from those of Carreras and Prados de la Escosura. Thus, from this new point of view, Carreras overestimated cotton and underestimated wool whereas Prados de la Escosura does exactly the opposite.

With the new estimates of the textile and metal industries and the new (internal) share of textiles, it can be estimated two alternative industry indices. Both of which are modifications of the original Prados de la Escosura industrial index. ${ }^{40}$ In the first (Spain Industry A) index of industrial output, we assume that the textile and metal industries in Spain had the same growth rates as equivalent Catalan

${ }^{39}$ Unfortunately, the coverage of Gimenez Guited for the other major industrial sectors is patchy. In particular, food is underrepresented since only flour, oil refining and spirits were considered.

${ }^{40}$ Prados de la Escosura (1988), pp. 143-168. 
industries. In the second (Spain Industry B), we consider that the non-Catalan industries maintained the growth rates computed by Prados de la Escosura. As in Catalan GDP, Industry A can be considered the upper bound whereas industry B the lower bound. These alternative annual rates of growth lie, again, between the estimates of Carreras and Prados de la Escosura.

Table 7. Contribution to Overall Growth Rates: Catalan Industry, 1830-1860

\begin{tabular}{|c|c|c|c|c|}
\hline & & $\begin{array}{c}\text { Overall } \\
\text { Growth Rate } \\
\text { (percent) } \\
\text { (a) }\end{array}$ & $\begin{array}{l}\text { Share Catalan } \\
\text { industry in } \\
\text { value-added } \\
\text { (percent) } \\
\text { (b) } \\
\end{array}$ & $\begin{array}{l}\text { Contribution } \\
\text { growth rates } \\
\text { (percent) } \\
\text { (c) }\end{array}$ \\
\hline \multirow[t]{2}{*}{ Catalonia } & (1) GDP A & 2.57 & 29.3 & $34.3-60.4$ \\
\hline & (2) GDP B & 1.62 & 29.3 & $54.2-95.4$ \\
\hline \multirow[t]{5}{*}{ Spain } & (2) Industry A & 3.32 & 19.9 & $18.0-31.7$ \\
\hline & (3) Industry B & 2.99 & 19.9 & $20.0-35.2$ \\
\hline & (4) GDP A & 1.29 & 3.9 & $9.1-16.1$ \\
\hline & (5) GDP B & 1.21 & 3.9 & $9.7-17.0$ \\
\hline & (6) GDP C & 0.88 & 3.9 & $13.3-23.4$ \\
\hline
\end{tabular}

Notes and sources: The growth rates have been computed under the assumption that the growth rates of Catalan industry during the period 1830-60 were identical to those in the period 1840-61. Catalan GDP A and B: see text. Spain Industry A and B: see text. GDP A: Prados de la Escosura index of Spanish GDP (Prados de la Escosura (1988), pp. 38-47) computed with the Industry A. GDP B: the same than GDP B but calculated with Industry B. Spain GDP C: Mulhall's estimates of current Spanish GDP (Prados de la Escosura (1982), pp. 110) deflated with Sardá wholesale prices index. The contribution in the column $c$ is the result of to multiply the range of Catalan industry growth rates (see text) by the share of the column $\mathrm{b}$ and to divide by the growth rate of the column a.

The range of estimates based on different assumptions suggests similar conclusions. The contribution of the Catalan industry to Catalan GDP was larger. In Catalan GDP A, industry is the main factor in Catalan growth whereas in GDP B practically the unique factor. Another relevant result concerns the contribution of modern industries to Catalan growth; the contribution is between 34 and 54 
percent. ${ }^{41}$ The image of early industrialisation as one in which modern industries produced strong changes at regional level is fully proved.

By contrast, the contribution of Catalan industry to Spanish figures was less important. Particularly, the contribution of Catalan to Spanish industry varies from about 18 percent to about 35 percent. It is noteworthy that the widespread industrialisation at Spanish level required that more than one region experienced industrialising processes. Similarly, the role of the leading sectors is relatively small (about one fifth). From this last result, it can also be inferred that broad industrialisation demanded that traditional industries experienced large growth rates. Indeed, the contribution of Catalan industry to Spanish GDP is also small from about 9 percent to about 23 percent.

\section{Conclusions}

The main arguments can be re-stated as follows. First, I would stress that the results of the first section indicate the importance of quality in industrial growth during this period. Consequently, this paper provides a serious quantitative challenge to previous estimates of industrial output that did not take into account this issue. Second, I have made further revisions of the earlier estimates by means of the Törqvist indices in the course of the second section; these are generally fairly small in overall growth rates but tend to change the internal contribution of each sector. Third, I accept that the measurement of growth yields only a range of best guest estimates and that the coverage of the new index is not complete. However, it is important not to exaggerate the degree of scepticism. Fourth, I point out that Catalonia experienced the beginnings of industrialisation during this period. Finally, I demonstrate that despite the impressive growth rates in several modern industries, early industrialisation in Spain remains a regional phenomenon. Overall, during this early period of industrialisation, rapid growth rates in Spanish GDP were only

${ }^{41}$ It must be remembered that the lower contribution of industry to overall growth rates corresponds to the case when the rate of growth of the traditional industries is equal to zero. Consequently, it can be interpreted as the direct contribution of the modern industries to overall growth rates. 
possible when traditional sectors experienced similar growth rates to those found in the modern industries.

Appendix 1. Indices of cotton Industry, 1830-1861

\begin{tabular}{|c|c|c|c|c|c|}
\hline & Spinning & Weaving & Finishing & $\begin{array}{r}\text { Pure } \\
\text { Quantity }\end{array}$ & $\begin{array}{l}\text { Sectoral } \\
\text { Output }\end{array}$ \\
\hline 1830 & 100 & 100 & 100 & 100 & 100 \\
\hline 1831 & 102.2 & 103.75 & 103.49 & 102.03 & 103.4 \\
\hline 1832 & 101.21 & 103.95 & 103.69 & 99.36 & 103.53 \\
\hline 1833 & 98.98 & 102.68 & 102.43 & 96.69 & 102.21 \\
\hline 1834 & 96.69 & 102.07 & 101.83 & 94.02 & 101.5 \\
\hline 1835 & 88.75 & 94.65 & 94.85 & 84.43 & 94.46 \\
\hline 1836 & 101.05 & 108.58 & 108 & 101.1 & 107.56 \\
\hline 1837 & 117.73 & 127.84 & 126.31 & 116.03 & 125.76 \\
\hline 1838 & 141.62 & 155.52 & 152.63 & 139.63 & 151.93 \\
\hline 1839 & 121.31 & 137.61 & 136.02 & 107.62 & 135.1 \\
\hline 1840 & 201.74 & 235.65 & 229.16 & 204.99 & 227.46 \\
\hline 1841 & 232.61 & 277.96 & 267.35 & 206.5 & 265.21 \\
\hline 1842 & 156.67 & 189.95 & 184.23 & 120.57 & 182.57 \\
\hline 1843 & 86.85 & 106.47 & 105.99 & 65.31 & 104.88 \\
\hline 1844 & 172.26 & 214.41 & 204.82 & 172.99 & 202.85 \\
\hline 1845 & 306.12 & 392.5 & 371.54 & 376.86 & 367.74 \\
\hline 1846 & 343.52 & 452.27 & 425.34 & 168.59 & 420.78 \\
\hline 1847 & 218.26 & 293.35 & 281.27 & 181.5 & 278.01 \\
\hline 1848 & 300.77 & 402.71 & 385.77 & 262.81 & 381.34 \\
\hline 1849 & 358.73 & 478.59 & 458.55 & 301.87 & 453.32 \\
\hline 1850 & 433.56 & 620.69 & 653.25 & 379.35 & 644.1 \\
\hline 1851 & 532.47 & 751.19 & 777.54 & 359.78 & 766.96 \\
\hline 1852 & 499.74 & 695.38 & 696.74 & 388.77 & 687.89 \\
\hline 1853 & 480.16 & 668.25 & 663.5 & 364.66 & 655.19 \\
\hline 1854 & 470.54 & 657.27 & 665.26 & 356.81 & 656.6 \\
\hline 1855 & 536.18 & 750.27 & 771.35 & 417.33 & 761.03 \\
\hline 1856 & 601.3 & 837.23 & 840.97 & 628.73 & 830.23 \\
\hline 1857 & 685.91 & 953.13 & 947.75 & 346.34 & 935.91 \\
\hline 1858 & 678.26 & 941.97 & 927.35 & 455.97 & 915.99 \\
\hline 1859 & 605.73 & 836.22 & 802.52 & 530.43 & 793.32 \\
\hline 1860 & 592.34 & 818.58 & 787.41 & 516.56 & 778.32 \\
\hline 1861 & 622.6 & 857.14 & 825.2 & 488.53 & 815.74 \\
\hline
\end{tabular}




\section{References}

Arau, N. (1855). Tratado completo de la hilatura del algodón. Barcelona: Imprenta Luís Tasso.

Benaül, J.M. (1991). "La llana". In Nadal, J. Maluquer de Motes, J. and Cabana, F. (eds). Història Económica de la Catalunya contemporània 3. Barcelona: Enciclopèdia Catalana, pp. 87-158.

Calvet, D. (1857). "Sección práctica: Hilatura de Algodón". Revista Industrial.

Carreras, A. (1990). Industrialización española: estudios de historia cuantitativa. Madrid: Espasa Calpe.

Carreras, A. and Yañez, C. (1992). "El puerto en la era industrial: una sintesis histórica". In Clavera, J., Carreras, A., Delgado, J.M. and Yañez, C. Economia e historia del Puerto de Barcelona. Tres Estudios. Madrid: Civitas-Port Autònom de Barcelona, pp. 81-157.

Cerdá, I. (1968 [1867]). Monografía estadística de la clase obrera de Barcelona en 1856. Madrid: Instituto de Estudios Fiscales.

Comisión de Fábricas (1846). Exposición razonada que en forma de cartas dirige al Excelentísimo Señor Ministro de Hacienda la Comisión de fábricas. Barcelona: Imprenta y Libreria Oriental.

Comisión del Gobierno de S.M. (1841). Informe sobre algodones en rama y manufacturados que dió al Ministerio de Hacienda, con fecha 8 de agosto de 1840, una comisión nombrada por la Junta Revisora de los Nuevos Aranceles. Madrid: Imprenta Nacional.

Comisión Especial Arancelaria (1867). Información sobre el derecho diferencial de bandera y sobre los de aduanas exigibles a los hierros, al carbón de piedra y los algodones, presentada al gobierno de Su Majestad por la comisión nombrada de efecto en Real Decreto de 10 de noviembre de 1865. Madrid: Imprenta Nacional.

Crafts, N.F.R. (1985). British Economic Growth during the Industrial Revolution. Oxford: Clarendon Press.

Crafts, N.F.R. and Harley, C.K. (1992). "Output growth and the British industrial revolution: A restatement of the Crafts-Harley view". Economic History Review 45 (4), pp. 703-730.

Delgado, J.M. (1991). "El paper". In Nadal, J. Maluquer de Motes, J. and Cabana, F. (eds). Història Económica de la Catalunya contemporània. Barcelona: Enciclopèdia Catalana 3, pp. 203-232.

Diario de Barcelona (1866). Almanaque del Diario de Barcelona para 1867. Barcelona: I. de A. Brusi.

Diewert. W.E. (1987). "Index Numbers". In Eatwell, J. Milgate, M. and Neuman, P. (eds). The New Palgrave: A Dictionary of Economics 2. London: Mac Millan, pp. 767-780.

Diewert. W.E. and A.O. Nakamura (eds)(1993). Essays in Index Number Theory. 
Amsterdam: North-Holland.

Escribano, A. (1986). "La Maquinista Terrestre i Marítima". Recerques 18, pp. 141-160.

Ferrer Vidal, J. (1875). Conferencias sobre el arte de hilar y tejer en general y especialmente sobre el de hilar y tejer el algodón. Barcelona: Establecimiento de Jaime Jepús Roviralta.

Figuerola, L. (1968[1849]). Estadística de Barcelona en 1849. Madrid: Instituto de Estudios Fiscales.

Gimenez Guited, F. (1862). Guia fabril e industrial de España. publicada con el apoyo y autorización del gobierno de S.M. Madrid and Barcelona: Librería Española and Librería del Plus Ultra.

Gutiérrez, M.M. (1837). Impugnación a las cinco proposiciones de Pebrer sobre los grandes males que causa la ley de aranceles a la nación en general. a la Cataluña en particular, y a las mismas fábricas catalanas. Madrid: Imprenta de M. Calero.

Hill, P. (1993). "Price and volume Measures". In Eurostat, IMF, OECD, UN and World Bank (eds). System of National Accounts 1993. Bruxelles, Luxemburg, New York and Washington DC: Eurostat, IMF, OECD, UN and World Bank, pp. 379-406.

Huberman, M. (1996). Escape from the market. Negotiating work in Lancashire. Cambridge: Cambridge University Press.

Izard, M. (1969). La Revolución industrial en España: expansión de la industria algodonera catalana, 1832-1861. Mérida (Colombia): Universidad de los Andes.

Jorgenson, D.W. (1990). "Productivity and Economic Growth". In Berndt, E.R. and Triplett, J.E. (eds), Fifty Years of Economic Measurement. The Jubilee of the Conference on Research in Income and Wealth. Chicago: Nber-University of Chicago Press, pp. 19-118.

Madoz, P. (1846). Diccionario geográfico-estadístico-histórico de España y sus posesiones de ultramar. Madrid.

Maluquer de Motes, J. (1994). "El índice de la producción industrial de Cataluña. Una nueva estimación (1817-1935)". Revista de Historia Industrial 5, pp. 45-71.

Orellana, F.J. (1860). Reseña completa descriptiva y crítica de la Exposición Industrial y Artística de Productos del Principado de Cataluña improvisada en Barcelona para obsequiar a S.M. La Reina Doña Isabel II. Barcelona:Establecimiento Tipográfico de Jaime Jepús.

Prados de la Escosura, L. (1982). Comercio exterior y crecimiento económico en España, 1826-1913: Tendencias a largo plazo, Madrid: Banco de España.

Prados de la Escosura, L. (1983). "Producción y consumo de tejidos en España, 1800-1913: Primeros resultados". In Anes, G. Rojo, L.A. and Tedde, P. (eds). Historia económica y pensamiento social. Madrid: Alianza-Banco de España, pp. 455-471.

Prados de la Escosura, L. (1984). "El comercio hispano-británico en los siglos XVIII y XIX". Revista de Historia Económica 2 (2), pp. 113-162. 
Prados de la Escosura, L. (1988). De Imperio a nación. Madrid: Alianza Universidad.

Ronquillo, J.O. (1851-1857). Diccionario de materia mercantil, industrial y agrícola. Barcelona: Imprenta Gaspar.

Sardá, J. (1948). La política monetaria y las fluctuaciones de la economia española en el siglo $X I X$. Madrid: Instituto Sancho de Moncada.

Sayró, E. (1842). Industria algodonera de Cataluña. Madrid: Imprenta Nacional.

Sudrià, C. (1983). "La exportación en el desarrollo de la industria algodonera española, 18751920". Revista de Historia Económica 1 (2). pp. 369-386. 